\title{
APPLICATION OF COMPUTER-BASED TOOLS FOR MATHEMATICS TEACHING AT VARIOUS TYPES OF LESSONS IN GYMNASIUMS
}

\author{
Tetiana Tabler \\ Postgraduate Student at the Department of Pedagogy and Pedagogical Skills, \\ Bohdan Khmelnitsky Melitopol State Pedagogical University, Ukraine \\ e-mail: tabler1988@gmail.com,orcid.org/0000-0002-5489-3874
}

\section{Summary}

The article analyzes the classification of types of lessons in didactics and, in particular, types of lessons in mathematics. Mathematics lessons are divided into five types: a lesson of presenting new knowledge; a lesson of consolidation of the studied material, in particular, a lesson of formation of skills and abilities; a lesson of repetition, systematization, and generalization of the studied; knowledge testing and assessment lesson and combined lesson. You can get a computer tool for each type of the lesson and, accordingly, for its purpose and its structural elements. Despite of the modern information space is sufficiently filled with a variety of computer tools, it is important for teachers to quickly determine which tool is right for a particular type of lesson.

We propose to divide computer learning tools into three levels of interactivity: I level of interactivity - reactive interaction; II level of interactivity - active interaction; III level of interactivity - mutual interaction. The experience of teachers is analyzed and it is established at which structural stages of the lesson teachers use different computer tools, we offer a classification of computer teaching aids depending on the level of interactivity and type of lesson. The positive experience of the interactive catalog of computer tools developed and implemented by us in the lessons of mathematics confirmed our assumption that for each type of lesson a corresponding computer tool of different levels of interactivity is selected.

Keywords: interactive catalog of computer tools, mathematics lesson, levels of interactivity, structural stages of the lesson, didactic purpose of the lesson, the Grades 5-9; electronic teaching aids.

DOI: https://doi.org/10.23856/4216

\section{Introduction}

According to the State Standard of Basic and Complete General Secondary Education (November 23, 2011, № 1392) the main goal of the educational field "Mathematics" is the formation of students' mathematical competence at a level sufficient to ensure life in the modern world, successful acquisition of knowledge from other educational industries in the process of schooling, ensuring the intellectual development of students, the development of their attention, memory, logic, the culture of thinking and intuition (Derzhavnyi standart bazovoi i povnoi zahalnoi serednoi osvity). In the "Conceptual principles of secondary education reform", one of the main acquired competencies include mathematical competence, which includes a culture of logical and algorithmic thinking; ability to apply mathematical (numerical and geometric) methods to solve applied problems in various fields of activity; ability to understand and use simple mathematical models; ability to build such models to solve problems. 
It is not enough to use traditional methods and means of teaching mathematics, for the implementation and acquisition of advanced competencies by students. In recent years, the amount of information has increased greatly, students must not only reproduce fragments of unsystematized knowledge but also use them to solve life problems. Methods and means of teaching in a modern Ukrainian school must also be modern, which in turn motivates students to learn.

Therefore, the process of teaching mathematics in high schools should take place with the help of modern computer teaching aids of different levels of interactivity, so that teachers can work with data sets, draw and present conclusions, work together online in educational, social, and scientific projects and easily choose the right pedagogical software for each type of lesson.

The purpose of this article is to analyze the experience of using computer-based teaching aids in mathematics lessons and their distribution by levels of interactivity according to the types and structural stages of the mathematics lesson.

Types of math lessons. Let's move on to the types of lessons. In didactics, there are different classifications of types of 1 essons, which are based on different approaches, for example, the logical content of the work; in order to organize the material studied and the level of education of students; by the predominant component of the lesson; on didactic tasks solved in the lesson, etc. Summarizing the views of teachers V. Chaika (Chaika, 2011), I. Zaichenko (Zaichenko, 2016), O. Vyshnevskyi (Vyshnevskyi, 2008), M. Fitsula (Fitsula, 2006) we have that in modern theory and practice of teaching classification is used, which is based on the didactic purpose and place of the lesson in the general system of lessons (K. Ushinsky, B. Yesipov, M. Mahmutov, V. Onyschuk).

Methodist of Mathematics Z. Sliepkan (Sliepkan, 2006) pointed out that in the methodology of teaching mathematics the most common is also the classification, which is based on the didactic purpose of the lesson and contains the following types of lessons: 1) a lesson of presenting new knowledge; 2) a lesson of consolidation of the studied material, in particular, a lesson of formation of skills and abilities; 3 ) a lesson of repetition, systematization, and generalization of the studied; 4) a lesson of testing and assessment of knowledge; 5) a combined lesson, which combines different goals and types of educational work (work to consolidate previously learned, learning new learning material, developing practical skills, etc.). Each lesson has its own didactic purpose and for each type of lesson, you can make focused content and divide the lesson into structural stages.

Methodists of Mathematics R. Stolyar, A. Cherkasov (Cherkasov \& other, 1992) referring to the "general didactic structure" in pedagogy, divide the structure of the lesson into three components: 1 . The actualization of previous knowledge and methods of action; 2 . Formation of new knowledge and methods of action; 3. Application - the formation of skills and abilities. By breaking down each component of the general didactic structure, we get more specific stages of the learning process in a math lesson, which can occur in different sequences and relationships.

Thus, the generalized opinion of the didactics of mathematics G. Bevza, A. Stolyara, R. Cherkashina, Z. Sliepkan is the presence in the mathematics of the following main stages of the lesson: 1. Statement of goals and objectives of the lesson; 2. Acquaintance with new material; 3. Consolidation of new material: a) at the level of reproduction of information and methods of activity; b) at the level of creative application and acquisition of new; 4 . Test of knowledge, skills, and abilities. 
Depending on the type of lesson, the sequence of these stages may vary, the choice of teaching methods and tools depends on the goals and objectives set by the teacher in a particular lesson.

\section{Experience in the use of computer tools and their distribution by levels of interactivity and types of lessons}

You can get a computer tool for each type of lesson and, accordingly, for its purpose and its structural elements. Exploring the modern information space for teaching mathematics, we looked at about 80 different computer tools, which include software products, electronic educational resources, cloud technologies, Web 2.0 services, and more. Given this number of tools, it is important for teachers to quickly determine which tool is right for a particular type of lesson. After analyzing the scientific work of teachers M. Zhaldaka, Yu. Goroshko, Yu. Vinnychenko (Zhaldak, M.I. \& other, 2009), V. Bykova, M. Kademiia (Kademiia, 2013), Yu. Triusa (Tryus, 2005), T. Kramarenko (Kramarenko, 2008), F. Wilson, D. Miller (Wilson F. \& other) and many others; viewing blogs of mathematics teachers (O. Zhukova, I. Tabarchuk, Yu. Kramska, V. Voloshyna, Yu. Didenko); search for information on the Internet; participation in the webinar "Online tests: principles of successful interaction during distance learning" (certificate № B272-697852 from 28.04.2020) from the educational project of LLC "Na Urok”; participation in master classes from the Distance Academy of VG "Osnova" on the topics: "The art of creating interactive presentations. Review of modern services" (certificate MK-SR№ 004805), "Creation of Sway presentations and their application in the educational process" (certificate 09a25640-6004-11e8-93fc-917d29263cce) and distance learning according to the program of advanced training in the field: use of information and communication and digital technologies in the educational process on the web platform Unity.Ukr (certificate № 106134 from 01/03/2020, , conducted on the basis of the Melitopol Bohdan Khmelnytsky State Pedagogical University certification courses "Pedagogical software "Interactive Poster Designer"" for teachers of mathematics in Melitopol and as a result of the analysis of the questionnaire, we determined which computer tools exist and which are popular among teachers. In previous works (Tabler, 2020) we have repeatedly pointed out that there is no single classification of computer-based teaching aids and proposed to classify them by levels of interactivity because according to each level there are certain requirements for the tool, and the teacher will choose the tool according to the type of lesson.

Recall these levels. Let's turn to teachers G. Astvacaturov and L. Kochegarova (Astvacaturov, \& other, 2012), who distinguish three levels of interactivity, and to scientists Bent B. Andresen and Katie van den Brink (Bent B. Andresen, \& other 2007), who also consider the same levels interactivity in terms of multimedia computer tools.

And the level of interactivity: reactive interaction - users react to the situations offered to them, the sequence of situations is fixed and the possibilities of program control are insignificant: start, stop, return to the previous fragment.

Level II interactivity: active interaction - users control the program, ie decide for themselves in what order to perform tasks and which way to follow in the study of material, control over the program or electronic educational resource, choice of pace, volume, the trajectory of the educational task.

Level III interactivity: mutual interaction, which involves modeling and constructing a lesson using the tools of the learning environment, through the solution of complex learning problems, and users and programs are able to adapt to each other, for example in virtual reality programs. 
We will analyze the work of teachers on the use of computer tools in mathematics lessons in different types of lessons, give some examples, and based on the proposed classification, we will distribute them according to the level of interactivity.

1) T. Kramarenko (Kramarenko, 2008: 83) in the lesson of presenting new knowledge, suggests using the computer tool "Library of electronic visuals "Geometry, 7-9 class" when studying the topic "Similarity of triangles". During the traditional explanation of the material using this tool, the degree of student activity in the classroom, and the management of the program are insignificant, then this tool is classified as level I interactivity.

N. Tytarenko and E. Murtaziev (Tytarenko \& other, 2020) suggest using the computer tool GeoGebra to explain the new material. The teacher suggests using the basic construction of a geometric object and an alternative. For example, when studying the topic "Square", the basic construction will be a quadrilateral in which all sides are equal and an angle of $90^{\circ}$. Explaining the property of the square - "diagonals are perpendicular and equal", students can perform the second - an alternative drawing using and checking the specified property. In this way, you can explain all the properties of the square. Active work of students with the program allows them to carry it to the II level of interactivity.

2) Senior lecture L. Kvas (Kvas, 2017) in the lesson of consolidation of the studied material, in particular the lesson of formation of skills and abilities, considers the use of different programs. For example, the GRAN-2D program can be used in the formation of skills and abilities, as well as in testing knowledge. For example, in the 9th grade when studying the topic "Conversion of graphs of functions". You can use a problem-based learning method by changing the parameters of the schedules to ask students what will happen to the schedule and immediately demonstrate on the screen. For grades 5-6, he offers to use the Ukrainian educational portal for interactive learning of children with the help of interesting game tasks and Vchi.ua tasks. In this resource, the course of mathematics is divided into many interrelated interactive tasks, which allows you to build an individual educational trajectory for each student. Students are actively involved in the learning process and work with these tools, which allows them to be classified as level II interactivity.

3) In the lesson of systematization and generalization of the acquired knowledge P. Belchev, T. Tabler (Bielchev, \& other, 2012), offer tasks developed in the Smart Notebook, as an example, at the end of the lesson to conduct short-term independent work, if necessary, check it, in the middle of the screen is a timer that sounds after 4 minutes, indicating the end work. The activity of students during such work is not significant, so this tool is used with a minor user action, then this task is attributed to the first level of interactivity.

M. Kademiia (Kademiia, 2013: 27) invited students to participate in a Web-quest to improve the quality of physical and mathematical training of students, the structure of which is reflected on the main page of the Internet, which is based on the creation of Web 2.0 services. There is a mutual interaction between students and the computer and students with each other, they are actively involved in the learning process through the solution of complex problems, such tools are classified as level III interactivity.

4) Lesson of testing and assessment of knowledge. O. Gomora, a mathematics teacher at ZOSh№ 24, uses the online "Na urok" platform and a service provided free of charge by the platform for creating and conducting test tasks, for example, for the homework test. The activity is insignificant, so the tool is attributed to the first level of interactivity.

O. Semenikhina and N. Biloshapka (Semenikhina, \& other, 2018) suggest the use of computer visualization tools in mathematics lessons, such as Intelligence Maps - these are hierarchical diagrams that are used to illustrate ideas, projects, tasks that are related with a central key concept and organized radially around it. Teachers distinguish the following programs: 
X-Mind, Free-Mind, Coggle, Mind-Meister. Students can create intelligence maps individually, as well as divided into teams, actively involved in the process. The means for creating such maps are classified as level III interactivity.

Thus, the experience of teachers and teachers of mathematics indicates that, depending on the purpose and objectives, for a particular lesson you need to choose a tool for different levels of interactivity. Here is a conditional distribution of computer-based learning tools according to the levels of interactivity, according to the type and structural stage of the lesson (Table 1).

Table 1

Levels of computer interactivity according to the type and structural stage of the lesson

\begin{tabular}{|c|c|c|}
\hline $\begin{array}{c}\text { Level of computer } \\
\text { interactivity }\end{array}$ & Lesson type & Structural stage \\
\hline \multirow[t]{4}{*}{ 1st level of interactivity } & $\begin{array}{l}\text { A Lesson of presenting new } \\
\text { knowledge }\end{array}$ & $\begin{array}{l}\text { Actualization of basic knowledge; } \\
\text { Explanation of new material }\end{array}$ \\
\hline & $\begin{array}{l}\text { A lesson of consolidation of } \\
\text { the studied material, in par- } \\
\text { ticular a lesson of formation } \\
\text { of skills and abilities. }\end{array}$ & $\begin{array}{l}\text { Actualization and correction of basic } \\
\text { knowledge, skills and abilities; } \\
\text { Study (repetition) of educational mate- } \\
\text { rial (introductory, motivational and } \\
\text { cognitive exercises). }\end{array}$ \\
\hline & $\begin{array}{l}\text { A lesson of repetition, sys- } \\
\text { tematization and generaliza- } \\
\text { tion of the studied. }\end{array}$ & $\begin{array}{l}\text { Update and correction of basic knowl- } \\
\text { edge, skills and abilities. } \\
\text { Reproduction and adjustment of basic } \\
\text { knowledge. }\end{array}$ \\
\hline & $\begin{array}{l}\text { Lesson for testing and } \\
\text { assessing knowledge. }\end{array}$ & $\begin{array}{l}\text { Homework check. } \\
\text { Update and correction of basic knowl- } \\
\text { edge, skills, and abilities }\end{array}$ \\
\hline \multirow[t]{4}{*}{ 2nd level of interactivity } & $\begin{array}{l}\text { A lesson in presenting new } \\
\text { knowledge }\end{array}$ & $\begin{array}{l}\text { Generalization and systematization of } \\
\text { new knowledge. }\end{array}$ \\
\hline & $\begin{array}{l}\text { A lesson of consolidation of } \\
\text { the studied material, in par- } \\
\text { ticular a lesson of formation } \\
\text { of skills and abilities. }\end{array}$ & $\begin{array}{l}\text { Initial application of knowledge in order } \\
\text { to form a new skill (trial exercises); }\end{array}$ \\
\hline & $\begin{array}{l}\text { A lesson of repetition, sys- } \\
\text { tematization, and generaliza- } \\
\text { tion of the studied. }\end{array}$ & $\begin{array}{l}\text { Application of knowledge and skills } \\
\text { in standard conditions for the purpose } \\
\text { of formation of skills (training, fixing } \\
\text { exercises) }\end{array}$ \\
\hline & $\begin{array}{l}\text { The lesson for testing and } \\
\text { assessing knowledge. }\end{array}$ & $\begin{array}{l}\text { Generalization and systematization of } \\
\text { concepts. }\end{array}$ \\
\hline \multirow[t]{4}{*}{ 3rd level of interactivity } & $\begin{array}{l}\text { A lesson in presenting new } \\
\text { knowledge }\end{array}$ & $\begin{array}{l}\text { When working individually on home- } \\
\text { work }\end{array}$ \\
\hline & $\begin{array}{l}\text { A lesson of consolidation of } \\
\text { the studied material, in par- } \\
\text { ticular a lesson of formation } \\
\text { of skills and abilities. }\end{array}$ & $\begin{array}{l}\text { Creative transfer of knowledge and } \\
\text { skills to new situations in order to form } \\
\text { complex skills (creative exercises). }\end{array}$ \\
\hline & $\begin{array}{l}\text { A lesson of repetition, sys- } \\
\text { tematization, and generaliza- } \\
\text { tion of the studied. }\end{array}$ & $\begin{array}{l}\text { Assimilation of leading ideas and } \\
\text { theories on the basis of broad system- } \\
\text { atization. }\end{array}$ \\
\hline & $\begin{array}{l}\text { Lesson for testing and } \\
\text { assessing knowledge. }\end{array}$ & $\begin{array}{l}\text { Use of skills to apply knowledge in } \\
\text { standard and non-standard conditions. }\end{array}$ \\
\hline
\end{tabular}




\section{Introduction of an interactive catalog of computer tools}

Based on the experience of teachers and taking into account this division, we have developed an interactive catalog of computer tools to use in high school math lessons (Fig. 1). To create this catalog, we used the author's pedagogical software "Interactive lessons designer" (authors P. Belchev, T. Tabler) as a designer, and we created the design and background images using Prezi.com. Elements of this catalog are interactive. Computer-based learning tools are divided into three levels of interactivity: The 1st level of interactivity; The 2nd level of interactivity; The 3rd level of interactivity. Going to the appropriate level, we have the means, which are divided into types of lessons.

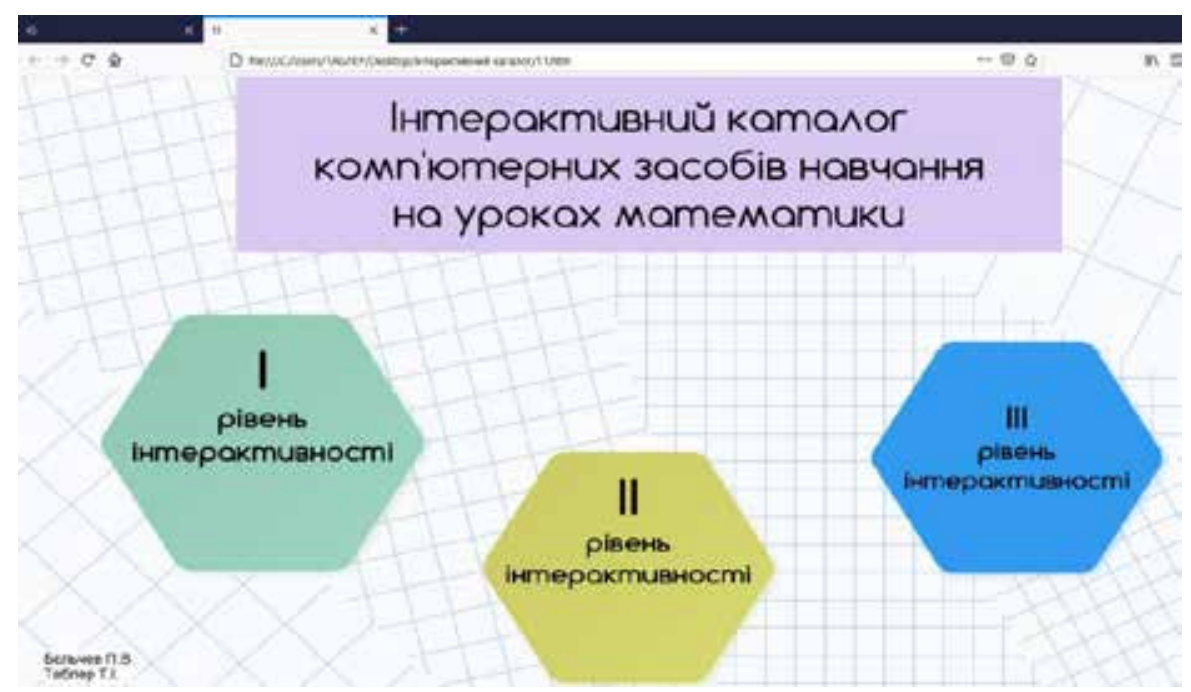

Fig. 1. Interactive catalog of teaching aids in mathematics lessons

For example, consider a page with the means of the second level of interactivity (Fig. 2).

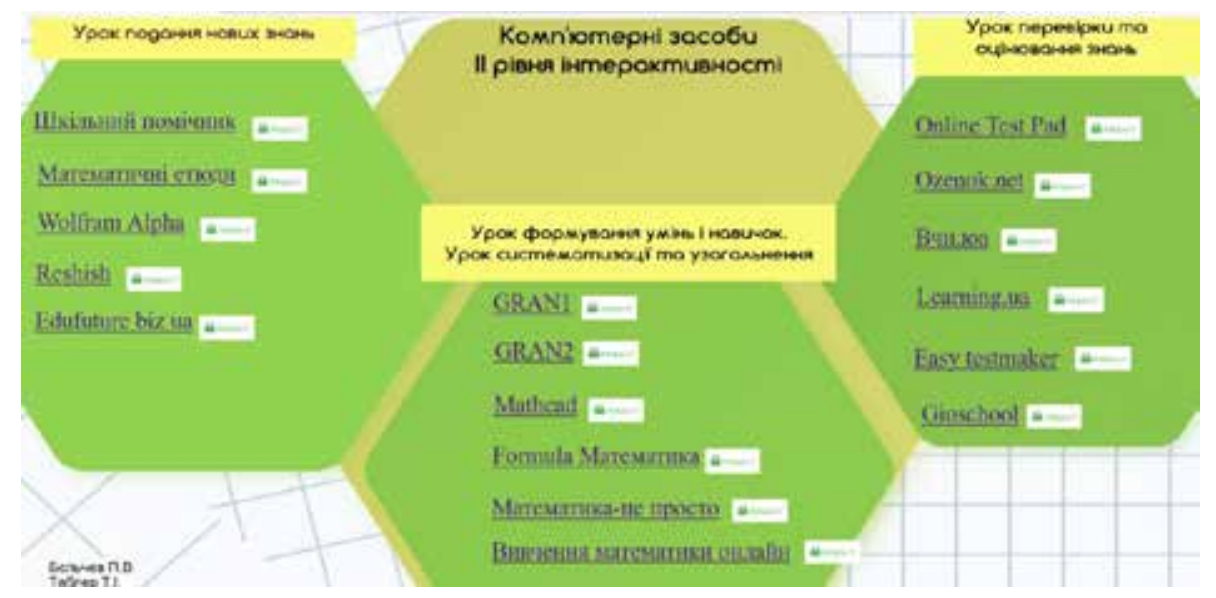

Fig. 2. Level II Interactive Computer Tools 
In the form of a list for each type of lesson are the names of computer tools and next to each tool is an element with the image "https: //" when hovering over a particular element, it increases, and below it appears a brief description of the tool in front of it. For example, if we bring to Gran 2 we will see a window as in Fig. 3. You can go to the site with this tool by clicking on the name of the tool or the element "https: //".

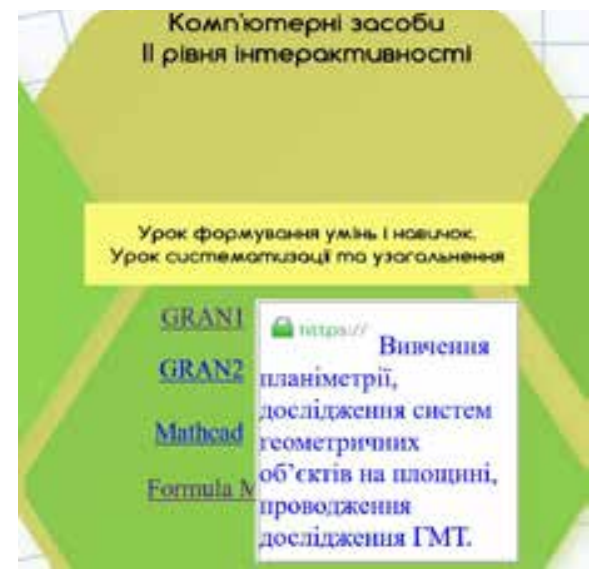

\section{Fig. 3. Enlarged element with a brief description of Gran 2 (study of planimetry, study of systemsgeometric objects on the plane, research)}

This tool was tested during active pedagogical practice at the University at the Department of Mathematics and Physics of Melitopol State Pedagogical University named after Bohdan Khmelnytsky and was presented at the methodological seminar of the department, where it received positive feedback and was recommended for implementation in the educational process (protocol № 2 from the 2020 year). During the cooperation with the Methodical Association of Mathematics Teachers of Melitopol and the introduction of this product in the educational process, it was found that the interactive catalog is easy to use and is a relevant tool, as teachers actively use and implement computer tools in their work. a priority of modern education.

\section{Conclusion}

The experience of using computer-based learning tools of different levels of interactivity at different structural stages of the lesson indicates that math lessons become rich, bright and dissimilar, more effective in distance learning, which promotes student interest, enhances cognitive activity, and motivates them to study.

During the testing of the interactive catalog, we found that due to a large number of teaching aids there is a lack of a systematic list of software tools to support the teaching of mathematics. Therefore, the prospect of further research is to create an alternative tool, where the distribution of computer tools will be as follows: the teacher chooses the type of lesson; purpose and objectives; structural stage of the lesson; the level of interactivity of the tool and, directly, the tool itself. We also plan to develop an interactive catalog of computer tools for use in high school math classes according to the list of topics in current algebra and geometry programs. 


\section{References}

Astvacaturov G.O., \& Kochegarova L.V. (2012). Jeffektivnyj urok v mul'timedijnoj obrazovatel'noj srede (prakticheskoe posobie) [Effective lesson in a multimedia educational environment (practical guide)]. Moscow: Sentjabr' [in Russian].

Bent B. Andresen, Katya van den Brink (2007) Multimedia v obrazovanii: specializirovannyj uchebnyj. [Multimedia in education: specialized educational] Moskva: Drofa [in Russian].

Bielchev P.V., \& Tabler T.I. (2012). Realization of modern principles of teaching mathematics with the help of an interactive whiteboard Smart Board [Implementation of modern principles of teaching mathematics with the help of an interactive board Smart Board.] Higher Education of Ukraine in the Context of Integration into the European Educational Space, Annex 1 to Issue 27, Vol. IV (37), Kyiv, PP. 36-42 [in Ukrainian].

Chaika, V.M. (2011). Osnovy dydaktyky: navchalnyi posibnyk [Basics of didactics: a tutorial]. Kyiv: Akademvydav [in Ukrainian].

Cherkasov, R.S., \& Stolyar, A.A. (1992). Metodyka vykladannia matematyky v serednii shkoli [Methodology of teaching mathematics in high school]. Kharkiv: Osvita [in Ukrainian].

Derzhavnyi standart bazovoi i povnoi zahalnoi serednoi osvity [State standard of basic and complete general secondary education] (n.d.). zakon.rada.gov.ua. Retrieved from: https:// zakon.rada.gov.ua/laws/show/1392-2011-\%D0\%BF\#Text [in Ukrainian].

Fitsula, M.M. (2006). Pedahohika: navchalnyi posibnyk. [Pedagogy: A manual]. Kyiv: Akademvydav [in Ukrainian].

Kademiia, M.Iu (2013) Innovatsiini tekhnolohii u vykladanni fizyko-matematychnykh dystsyplin [Innovative technologies in the teaching of physical and mathematical disciplines] Suchasni informatsiini tekhnolohii ta innovatsiini metodyky navchannia u pidhotovtsi fakhivtsiv: metodolohiia, teoriia, dosvid, problemy: zb. nauk. pr. Kyiv-Vinnytsia: TOV firma "Planer”, vol. 36, pp. 25-28 [in Ukrainian].

Kramarenko, T.H. (2008) Uroky matematyky z kompiuterom. Posibnyk dlia vchyteliv $i$ studentiv [Computer math lessons. A guide for teachers and students]. Kryvyi Rih: Vydavnychyi dim [in Ukrainian].

Kvas, L.T. (2017) Vykorystannia elektronnykh osvitnikh resursiv na urokakh matematyky [Use of electronic educational resources in mathematics lessons]. Novitni informatsiino-komunikatsiini tekhnolohii u navchalnomu protsesi: aktualni problemy. Ternopil [in Ukrainian].

Semenikhina, O., \& Biloshapka, N. (2018) Pro vykorystannia vchyteliamy matematyky zasobiv kompiuternoi vizualizatsii [About the use of computer visualization tools by mathematics teachers]. Humanizatsiia navchalno-vykhovnoho protsesu. no. 1 (87), pp. 289-301 [in Ukrainian]. Sliepkan, Z.I. (2006). Metodyka navchannia matematyky: Pidruchnyk [Methodology for teaching mathematics: A textbook]. Kyiv: Vyshcha shk. [in Ukrainian].

Tabler, T.I. (2020) Do pytannia rozpodilu kompiuternykh zasobiv navchannia matematyky za rivniamy interaktyvnosti. [On the question of the distribution of computer aids for teaching mathematics by level of interactivity] Naukovyi zhurnal. Innovatsiina pedahohika. Prychornomorskyi naukovo-doslidnyi instytut ekonomiky ta innovatsii. Vydavnychyi dim "Helvetyka", vol. 22 (3), pp. 46-51. [in Ukrainian].

Tryus, Yu.V. (2005). Kompiuterno-oriientovani metodychni systemy navchannia matematyky: monohrafia [Computer-oriented methodical systems of teaching mathematics: monograph]. Cherkasy: Brama-Ukraina [in Ukrainian].

Tytarenko, N.Ie. \& Murtaziiev, E.H. (2020) Zastosuvannia GeoGebra na urokakh heometrii [Using GeoGebra in geometry lessons]. Vyshcha osvita Ukrainy u konteksti intehratsii do 
Yevropeiskoho osvitnoho prostoru: KhIV Mizhnarodna naukovo-praktychna konferentsiia. Kyiv. vol. III (81). pp. 203-209 [in Ukrainian].

Vyshnevskyi, O. (2008) Teoretychni osnovy suchasnoi ukrainskoi pedahohiky: Navchalnyi posibnyk [Theoretical foundations of modern Ukrainian pedagogy: Textbook]. Kyiv: Znannia [in Ukrainian].

Wilson F. \& Miller D. Enabling enhanced Mathematics teaching with interactive whiteboards. Retrieved from: wilsonmiller.pdf (nationalarchives.gov.uk) [in English].

Zaichenko, I.V. (2016). Pedahohika: pidruchnyk. [Pedagogy: textbook]. Kyiv: Lira-K [in Ukrainian].

Zhaldak, M.I., Horoshko, Yu.V., \& Vinnychenko, Ye.F. (2009) Matematyka z kompiuterom. [Computer math] Posibnyk dlia vchyteliv. Kyiv [in Ukrainian]. 